\title{
IgM-Immunofluorescence Test as a Diagnostic Tool for Epidemiologic Studies of Schistosomiasis in Low Endemic Areas
}

\author{
Herminia Yohko Kanamura/ ${ }^{+}$, Rita Maria da Silva*, Silvia Gabriel Chiodelli**, \\ Carmen Moreno Glasser***, Luiz Candido de Souza Dias****
}

\begin{abstract}
Departamento de Biologia, Universidade de Taubaté, Av. Tiradentes 500, 12030-010 Taubaté, SP, Brasil and Faculdade de Ciências Farmacêuticas, Universidade de São Paulo, São Paulo, SP, Brasil *Instituto Adolfo Lutz, Rio Claro, SP and Fauldade de Saúde Pública, USP, São Paulo, SP, Brasil **Instituto Adolfo Lutz, São Paulo, SP, Brasil ***Superintendência de Controle de Endemias, São Paulo, SP, Brasil ****Faculdade de Ciências Médicas, Universidade Estadual de Campinas, Campinas, SP, Brasil

The high sensitivity and the ability to diagnose schistosomiasis in a very early phase after infection have indicated the detection of IgM antibodies to Schistosoma mansoni gut antigens by the immunofluorescence test (IgM-IFT) as a useful serological test for epidemiological studies in low endemic areas. When applied in a followup study for two years, higher rates of seroconversion from IFT negative to positive were observed during the summer months, suggesting seasonal transmission of schistosomiasis in the rural area of the municipality of Itariri (São Paulo, Brazil). In each survey, blood samples from about 600 schoolchildren were collected on filter paper and submitted to IgM-IFT. When the blood samples were classified for the IgM antibody levels, according to the intensity of fluorescent reaction observed at fluorescence microscopy, and correlated to the egg counts in the Kato-Katz positive patients, no association was observed. This observation might suggest that the intensity of fluorescence observed in the IgM-IFT, as an indicator of IgM antibody levels, could not be an useful seroepidemiological marker for classifying areas of low endemicity according to degrees of infection.
\end{abstract}

Key words: Schistosoma mansoni - IgM - IFT - low endemic area - seroepidemiology

Schistosomiasis continues to be a serious problem of public health in Brazil (Graeff-Teixeira et al. 1999, Katz \& Peixoto 2000). In areas where schistosomiasis is endemic, the diagnosis of the infection is commonly based only on parasitologic methods. However, even after repeated stool examinations, those methods frequently fail to detect lowintensity Schistosoma mansoni infections (Barreto et al. 1990, De Vlas \& Gryseels 1992, Engels et al. 1996). In the State of São Paulo, Brazil, some areas are of low endemicity for schistosomiasis, and the majority of the individuals have low worm burden. Investigations in these areas have demonstrated that the prevalence rates obtained by serologic tests were always higher than the ones obtained by parasitologic methods. In such situation, the serologic methods can stand for an important tool to estimate prevalence rates closer to the real situation (Kawazoe et al. 1981, Hoshino-Shimizu et al. 1986, Dias et al. 1992).

The immunofluorescence test for the detection of IgM antibodies against $S$. mansoni gut associated polysaccharide antigens (IgM-IFT), on adult worm paraffin sections, showed high degree of sensitivity for diagnosis of both, acute and chronic schistosomiasis (Silva et al. 1992). The presence of cross reactive IgG antibodies in serum samples of schistosomiasis patients was detected by dif-

Financial support from Fapesp (Proc 92/2142-9 and 97/13904-0) ${ }^{+}$Corresponding author. Fax: +55-12-232.7660. E-mail: kanamura@usp.br

Received 20 August 2001

Accepted 26 February 2002 ferent authors when tested with antigens of other parasite species by ELISA and Western blot (Correa-Oliveira et al. 1988, Valli et al. 1997, 1999). Nevertheless, good specificity $(98.2 \%)$ was observed when detection of IgM antibodies to gut-associated antigens by IFT was applied in a different area of the State of São Paulo with no schistosomiasis and high prevalence for other helminth infections, such as ascaridiasis, trichuriasis, and enterobiasis (Kanamura et al. 1998a). The IgM-IFT was also demonstrated to be an important tool for field studies, in a low endemic area for schistosomiasis in São Paulo, where it was capable of demonstrating seasonal trends of transmission (Kanamura et al. 1998b).

In the present study we evaluated the possible use of the IgM antibody levels, detected against the $S$. mansoni gut-associated antigens, as a seroepidemiologic marker for classifying infected groups according to the intensity of infection.

\section{MATERIALS AND METHODS}

Studied area and population - The study was carried out in a rural village of the municipality of Itariri, in the Vale do Rio Ribeira de Iguape (São Paulo, Brazil), where the only intermediary host is the snail Biomphalaria tenagophila. The autochthonous schistosomiasis prevalence in the municipality of Itariri was $3.1 \%$, ranging from 0 to $9.2 \%$ in the different villages, according to the parasitological survey carried out in 1990. Intestinal helminth diseases such as ascaridiasis, trichuriasis, and enterobiasis were found in the studied population with prevalence rates of 52.5, 44.1 and $3.4 \%$, respectively. As already reported (Kanamura et al. 1998b), from 1991 to 1993, five surveys were carried out, one for each semester, follow- 
ing a group of about 650 schoolchildren by parasitologic (Kato-Katz) and serologic (IgM-IFT) diagnostic methods. Informed consent for participation in the study was obtained from the guardians. For the present study, about $30 \%$ of the children, in each survey, were selected by the simple randomized sampling method. From the 1 st to 5 th surveys respectively $242,223,242,234$ and 239 individuals were selected for evaluation according to the intensity of fluorescent staining by IgM antibodies.

Blood samples - Blood samples obtained from finger pricks were collected on Whatman ${ }^{\circledR} \# 3$ filter paper. The filter papers were dried at room temperature, stored in a plastic bag, and kept at $-20^{\circ} \mathrm{C}$. The dried blood spot discs were cut from the filter paper using a punch $8-\mathrm{mm}$ in diameter. The paper disc were eluted in $120 \mu \mathrm{l}$ of $0.01 \mathrm{M}, \mathrm{pH}$ 7.2, phosphate buffer solution (PBS), incubating overnight at $4{ }^{\circ} \mathrm{C}$. The serum dilution after elution and removal of the paper disc was estimated to be 1:16 (Ferreira \& Carvalho 1982) and used for the IgM-IFT.

$I g M-I F T$ - The immunofluorescence test for detection of IgM antibodies against gut-associated antigens was performed on paraffin sections of $S$. mansoni worms treated with Rossman's solution, as described (Deelder \& Kornelis 1980, Kanamura et al. 1991, 1998a).

Parasitological diagnosis - From each schoolchild, in each survey, one fecal sample was examined by the Kato-Katz method (Katz et al. 1972). S. mansoni egg counts were expressed in eggs per gram (epg), using the average of egg counts obtained from three slides for each sample.

Data analysis - The analysis of the sensitivity and specificity indices and the determination of Kappa indices to compare the performance of the diagnostic methods were done using the statistical package of EPIINFO (Dean et al. 1995).

\section{RESULTS}

The schistosomiasis prevalence rates, in each survey, obtained by the serologic IgM-IFT method were significantly higher than those obtained by the parasitologic Kato-Katz method (Fig. 1).

The comparative analysis between the results of the IgM-IFT and those obtained by Kato-Katz showed a very poor degree of agreement. The Kappa indices varied from 0.088 to 0.166 for the different surveys (Table). According to the data of the first survey, when the Kato-Katz technique was defined as a reference diagnostic method, the IgM-IFT presented a good sensitivity of $95.6 \%$ (95\% confidence interval: 83.6-99.2), and a low specificity of $48.3 \%$ (95\% confidence interval: 43.8-52.9). In the other surveys, the sensitivity rates varied from $90.9 \%$ to $100 \%$ and the specificity from $37.6 \%$ to $52.9 \%$

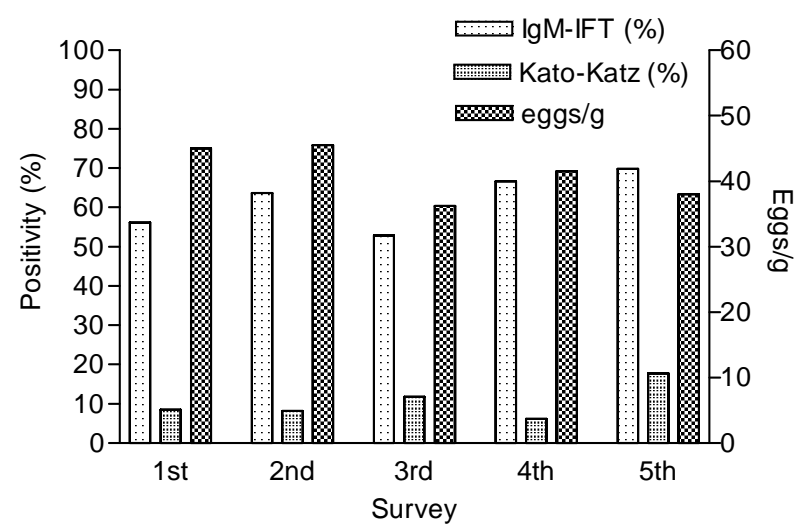

Fig. 1: positivity rates by serological (IgM-IFT) and parasitological (Kato-Katz) methods, in a schoolchildren population of Itariri, São Paulo (1991 to 1993)

TABLE

Comparative results between IgM-IFT and Kato-Katz methods, in each survey (Itariri, 1991 a 1993)

\begin{tabular}{|c|c|c|c|c|c|}
\hline \multirow{2}{*}{$\begin{array}{l}\text { Survey } \\
\text { (Period) }\end{array}$} & \multirow[b]{2}{*}{ Kato-Katz } & \multicolumn{3}{|c|}{ IgM-IFT } & \multirow[b]{2}{*}{ Kappa indices } \\
\hline & & $\mathrm{N}$ & $\mathrm{P}$ & Total & \\
\hline \multirow{3}{*}{$\begin{array}{c}1 \text { st } \\
\text { (1st semester/1991) }\end{array}$} & $\mathrm{N}$ & 233 & 249 & 482 & \multirow{3}{*}{$\begin{array}{c}0,126 \\
(0,085-0,166)^{a}\end{array}$} \\
\hline & $\mathrm{P}$ & 2 & 43 & 45 & \\
\hline & Total & 235 & 292 & 527 & \\
\hline \multirow{3}{*}{$\begin{array}{c}\text { 2nd } \\
\text { (2nd semester/1991) }\end{array}$} & $\mathrm{N}$ & 246 & 219 & 465 & \multirow{3}{*}{$\begin{array}{c}0,126 \\
(0,082-0,168)\end{array}$} \\
\hline & $\mathrm{P}$ & 1 & 33 & 34 & \\
\hline & Total & 247 & 252 & 499 & \\
\hline \multirow{3}{*}{$\begin{array}{c}\text { 3rd } \\
\text { (1st semester/1992) }\end{array}$} & $\mathrm{N}$ & 190 & 254 & 444 & \multirow{3}{*}{$\begin{array}{c}0,113 \\
(0,072-0,153)\end{array}$} \\
\hline & $\mathrm{P}$ & 5 & 50 & 55 & \\
\hline & Total & 195 & 304 & 499 & \\
\hline \multirow{3}{*}{$\begin{array}{c}\text { 4th } \\
\text { (2nd semester/1992) }\end{array}$} & $\mathrm{N}$ & 218 & 241 & 459 & \multirow{3}{*}{$\begin{array}{c}0,088 \\
(0,054-0,121)\end{array}$} \\
\hline & $\mathrm{P}$ & 0 & 26 & 26 & \\
\hline & Total & 218 & 267 & 485 & \\
\hline \multirow{3}{*}{$\begin{array}{c}\text { 5th } \\
\text { (1st semester/1993) }\end{array}$} & $\mathrm{N}$ & 170 & 282 & 452 & \multirow{3}{*}{$\begin{array}{c}0,166 \\
(0,128-0,202)\end{array}$} \\
\hline & $\mathrm{P}$ & 0 & 89 & 89 & \\
\hline & Total & 170 & 371 & 541 & \\
\hline
\end{tabular}

$a:(95 \%$ confidence interval); $\mathrm{N}$ : negative; $\mathrm{P}$ : positive 
The levels of the IgM antibodies detected against gutassociated antigens by the IgM-IFT, according to the intensity of reaction at the fluorescence microscopy, were classified in three grades: low, medium and high fluorescence intensity. The relative distribution of the low, medium and high fluorescence intensity reactions among the individuals with positive or negative results for $S$. mansoni eggs in the Kato-Katz method was presented on Fig. 2. The relative distribution of the fluorescence intensities according to the survey (Fig. 3) showed tendency for greater proportion of high fluorescence intensity reactions in the 2nd and 4th surveys, and of negative fluorescence reaction in the 1st and 3rd surveys. According to Fig. 4, no association was possible to be observed between fecal egg counts in the Kato-Katz method and fluorescence intensities of the blood samples in the IgMIFT.

\section{DISCUSSION}

The prevalence rates obtained by IgM-IFT were significantly higher than those obtained by the parasitological Kato-Katz method, confirming the lack of sensitivity of the latter in low endemic areas (Fig. 1). It is known that the commonly used Kato-Kato technique can give under-

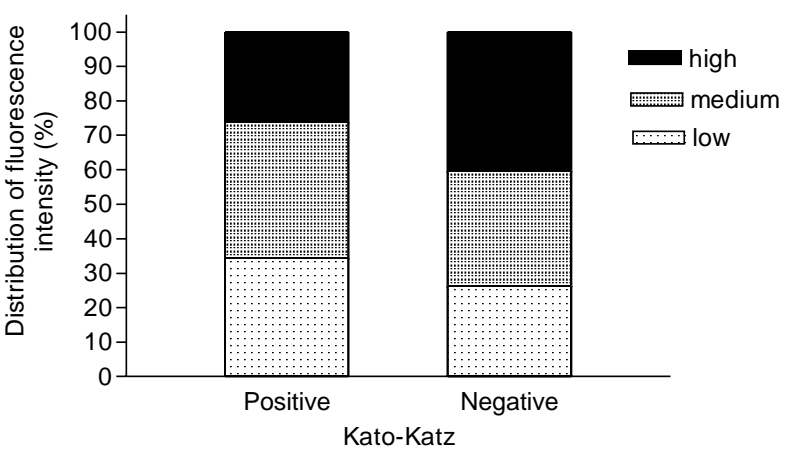

Fig. 2: relative proportions of high, medium and low fluorescence intensity reactions according to the Schistosoma mansoni positive or negative result in the parasitological Kato-Katz method.

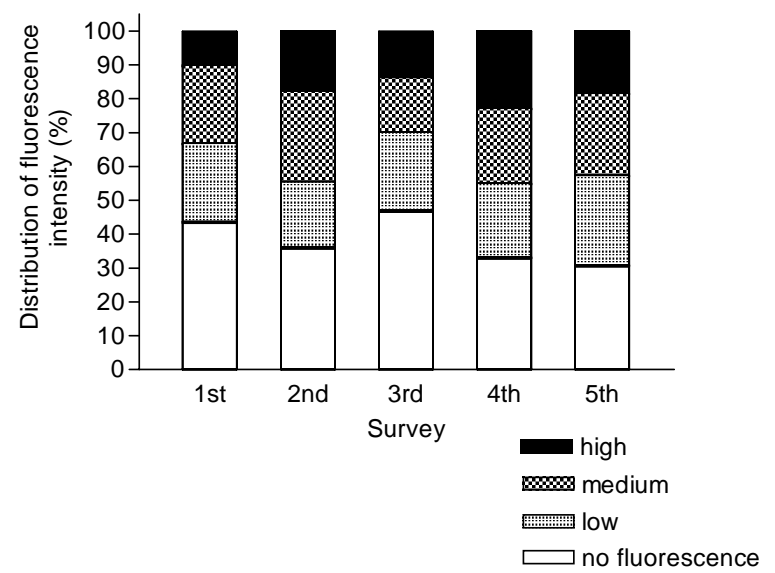

Fig. 3: relative proportions of high, medium and low fluorescence intensity reactions according to the survey.

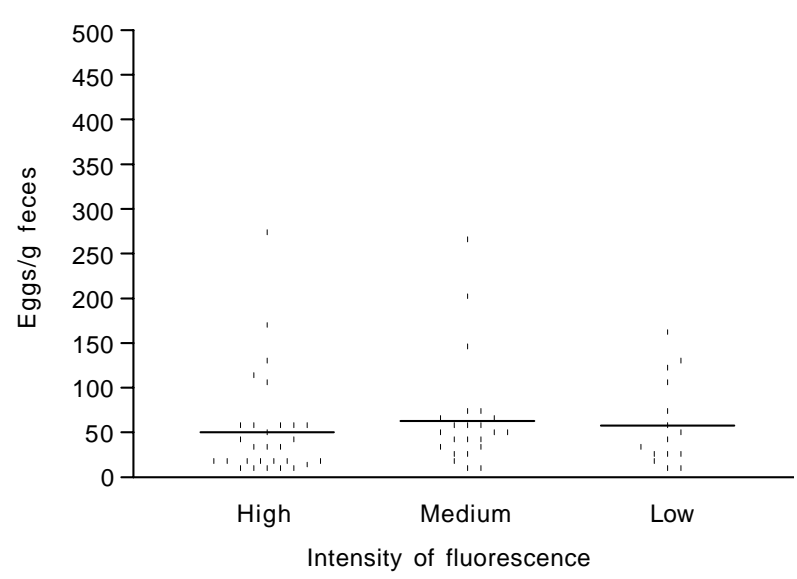

Fig. 4: distribution of intensities of fluorescence reaction according to the egg counts.

estimate prevalence indices when applied in low endemic areas, where the majority of the infected individuals used to excrete less than 100 eggs per gram of feces (De Vlas \& Gryseels 1992). The studied area, localized in the State of São Paulo, can be considered as low endemic area (Kanamura et al. 1998a). The egg counts in the parasitologically positive fecal samples from the individuals selected for this study varied from 8 to $1792 \mathrm{epg}$, with geometric means of 45.0, 45.5, 36.2, 41.5 and 38.0 epg, respectively for the 1st to 5 th surveys. Such low egg counts, indicating small number of parasites in the infected population, and the use of only one fecal sample from each individual are certainly the responsible for the reduced parasitological prevalence rates, when compared to the serological data.

When the results of the two diagnostic methods were compared, a very low grade of agreement was detected, as can be indicated by the analysis of the Kappa indices, varying from 0.088 to 0.166 in the different surveys. The discordant results were more frequently observed in the positive IgM-IFT and negative Kato-Katz cases. The good specificity of this test, with only $1.8 \%$ of false positive results, in a population with other helminth infection but no schistosomiasis, was previously reported (Kanamura et al. 1998a). So, the higher IgM-IFT prevalence rates obtained in comparison to the parasitological data might actually suggest an area with low worm burden, and not necessarily low endemicity.

In the present study, we evaluated the possible usefulness of the IgM antibody levels as a marker for intensity of infection for epidemiological purposes. The fluorescence reaction, categorized as low, medium and high intensity, can reflect respectively low, medium and high IgM antibody levels in the serum samples. When analyzed, in comparison to the quantitative results of the parasitological Kato-Katz method, no association between egg count and fluorescence intensity was observed (Fig. 4). Also, the relative proportion of individuals with high fluorescence intensity was greater in the $S$. mansoni egg 
negative group than in the positive group (Fig. 2). Higher immunofluorescence intensities can reflect higher IgM antibody levels. The presence of high levels of gut specific IgM antibodies in the recent phase of $S$. mansoni infection was demonstrated by Kanamura et al. (1979), when fluorescent staining patterns on adult worm cryostat sections were correlated to class-specific antibodies and clinical forms. In that paper (Kanamura et al. 1979), a diffuse pattern, as classified by Van Helden et al. (1975), was observed for IgG antibodies in chronic cases, with fluorescence of the whole parenchyma on worm cryostat sections. The focal pattern, corresponding to staining of intestinal epithelial cells, was observed for IgG antibodies only in the acute phase, and for IgA and IgM antibodies, in acute and chronic phases. IgM antibodies, staining only gut antigens, also in the chronic cases, proved to be valuable for the diagnosis of both acute and chronic schistosomiasis infections (Silva et al. 1992). On the other hand, the use of paraffin-embedded sections, because of its high stability at room temperature, showed to be a practical and useful test for epidemiological purposes (Kanamura et al. 1998a). Also, the high sensitivity of the IgM-IFT to detect antibody to gut antigens in a very early phase, starting from the second week of infection, was observed on experimentally infected mice and baboons (Kanamura et al. 1997, Garcia et al. 1999, Garcia 2000). These observations can partially explain our results, showing high levels of IgM antibodies in some individuals with no detectable S. mansoni eggs in the fecal examination (Fig. 2), and suggesting that they might be in a very early phase of infection. The number of individuals in such a situation seems to be relatively high in the studied area.

The relative proportions of negative IgM-IFT individuals (indicated as no fluorescence in the Fig. 3) were greater in the 1st and 3rd post-summer surveys than in the other surveys; oppositely the relative proportions of individuals with high fluorescence intensity were greater in the 2 nd and 4 th post-winter surveys. These observations can reflect tendency to seasonal transmission of schistosomiasis in the studied area. In previous paper (Kanamura et al. 1998b), seroconversion from IFT negative to positive, indicating newly acquired $S$. mansoni infection, was observed more frequently in surveys carried out during March-April (after summer holidays), than during September-October, suggesting trends to seasonal transmission. The relationship between that previous observation and occurrence of greater proportion of cases with high fluorescence intensity in the surveys carried out in the second semester (after winter holidays) must be better investigated.

The IgM-IFT, as applied in this study, could be an important tool for field studies, in low endemic areas. However the analysis of the fluorescence intensity, as a indicator for IgM antibody levels, seems to be not useful for classifying areas according to the level of $S$. mansoni transmission (Fig. 4). New studies must be carried out to better understand the meaning of the differences observed for the relative proportions in the intensities of the fluorescence reactions in the post-summer and post-winter surveys.

\section{REFERENCES}

Barreto ML, Smith DH, Sleigh AC 1990. Implications of faecal egg count variation when using the Kato-Katz method to assess Schistosoma mansoni infections. Trans $R$ Soc Trop Med Hyg 84: 554-555.

Correa-Oliveira R, Dusse LM, Viana IR, Colley DG, Carvalho OS, Gazzinelli G 1988. Human antibody response against schistosomal antigens. I. Antibodies from patients with Ancylostoma, Ascaris lumbricoides or Schistosoma mansoni infections react with schistosome antigens. Am J Trop Med Hyg 38: 348-355.

De Vlas SJ, Gryseels B 1992. Underestimation of Schistosoma mansoni prevalences. Parasitol Today 8: 274-277.

Dean AG, Dean JA, Coulombier D, Brendel KA, Smith DC, Burton H, Dicker RC, Sullivan KM, Fargan RF, Arner TG 1995. Epi Info, Version 6: a word processing, database, and statistics program for public health on IBM-compatible microcomputers, Centers of Disease Control and Prevention, Atlanta, GA.

Deelder AM, Kornelis D 1980. A comparison of the IFA and the ELISA for the demonstration of antibodies against schistosome gut-associated polyssacharide antigens in schistosomiasis. Z Parasitenk 64: 65-75.

Dias LCS, Camargo ME, Hoshino-Shimizu S, Ramos AA, Toledo Piza J, Silva LC 1971. Inquéritos populacionais de esquistossomose mansoni por técnicas sorológicas de imunofluorescência e de hemaglutinação. Rev Inst Med Trop São Paulo 13: 37-44.

Dias LCS, Kanamura HY, Hoshino-Shimizu S, Glasser CM, Carvalho JF, Silva LC 1992. Field trials for immunodiagnosis with reference to Schistosoma mansoni. In NR Bergquist, Immunodiagnostic Approches in Schistosomiasis, John Wiley \& Sons, Chichester, p. 39-47.

Engels D, Sinzinkayo E, Gryseels B 1996. Day-to-day egg count fluctuation in Schistosoma mansoni and its operational implications. Am J Trop Med Hyg 54: 319-324.

Ferreira CS, Carvalho ME 1982. Padronização de uso de papelfiltro como suporte de material para reações sorológicas. Rev Bras Malariol 34: 82-86.

Garcia ET 2000. Dinâmica da Resposta Imune Humoral Contra Antígenos Circulantes de Schistosoma mansoni no Modelo Experimental em Camundongos Pré e Pós Tratamento com Oxamniquine, MSc Thesis, Universidade de São Paulo, São Paulo, 94 pp.

Garcia ET, Kanamura HY, Melo MCC, Lima DMC 1999. Antibody response to gut associated circulating antigen in experimental Schistosoma mansoni infection in mice, before and after chemotherapy. Abstracts of the VII International Symposium on Schistosomiasis, Rio de Janeiro, p. 56.

Graeff-Teixeira, C, Anjos CB, Oliveira VC, Velloso CFP, Fonseca MBS, Valar C, Moraes C, Garrido CT, Amaral RS 1999. Identification of a transmission focus of Schistosoma mansoni in the southernmost Brazilian state, Rio Grande do Sul. Mem Inst Oswaldo Cruz 94: 9-10.

Hoshino-Shimizu S, Camargo ME, Kanamura-Kawada HY, Silva LC, Dias LCS 1986. Aspectos sorológicos e soroepidemiológico da esquistossomose mansônica, In FA Reis, I Faria, N Katz (eds), Modernos Conhecimentos sobre Esquistossomose Mansônica, Anais da Academia Mineira de Medicina, 14 (Supl.), p. 67-89.

Kanamura HY, Dias LCS, Silva RM, Glasser CM, Patucci RMJ, Vellosa SAG, Antunes JLF 1998a. A comparative epidemiologic study of specific antibodies (IgM and $\operatorname{IgA}$ ) and parasitological findings in an endemic area of low transmission of Schistosoma mansoni. Rev Inst Med Trop São Paulo 40: 85-91. 
Kanamura HY, Dias LCS, Glasser C M, Silva RM, Patucci RMJ, Chiodelli SG, Addis D 1998b. Detection of IgM antibodies to Schistosoma mansoni gut-associated antigens for the study of the dynamics of schistosomiasis transmission in an endemic area with low worm burden. Rev Inst Med Trop São Paulo 40: 225-231.

Kanamura HY, Hoshino-Shimizu S, Camargo ME, Silva LC 1979. Class specific antibodies and fluorescent staining patterns in acute and chronic forms of schistosomiasis mansoni. Am J Trop Med Hyg 28: 242-248.

Kanamura HY, Silva RM, Garcia ET, Chiodelli SG, Vellosa SAG, Gargioni C, Damian RT 1997. IgM and IgG antibody response in the primary and secondary Schistosoma mansoni infections in baboons. Abstracts of the VI International Symposium on Schistosomiasis, Belo Horizonte, p. 95.

Kanamura HY, Silva RM, Rabello ALT, Rocha RS, Katz N 1991. Anticorpos séricos IgA no diagnóstico da fase aguda da esquistossomose mansoni humana. Rev Inst Adolfo Lutz 51: 101-104.

Katz N, Peixoto SV 2000. Análise crítica da estimativa do número de portadores de esquistossomose no Brasil. Rev Soc Bras Med Trop 33: 303-308.

Katz N, Chaves A, Pellegrino J 1972. A simple device for quan- titative stool thick-smear technique in schistosomiasis mansoni. Rev Inst Med Trop São Paulo 14: 397-400.

Kawazoe U, Hoshino-Shimizu S, Correa NS, Silva LC, Pinto ACM, Camargo ME 1981. An immunoepidemiological study of schistosomiasis mansoni in Paraíba's Valley, São Paulo, Brazil. Rev Inst Med Trop São Paulo 23: 36-40.

Silva RM, Silva MIPG, Vellosa SAG, Kanamura HY 1992. Pesquisa de anticorpos IgM contra tubo digestivo do verme para o diagnóstico da esquistossomose mansônica. Rev Bras Pat Clin 28: 39-42.

Valli LCP, Kanamura HY, Silva RM, Ribeiro-Rodrigues R, Dietze $\mathrm{R}$ 1999. Schistosomiasis mansoni: immunoblot analysis to diagnose and differentiate recent and chronic infection. Am J Trop Med Hyg 61: 302-307.

Valli LCP, Kanamura HY, Silva RM, Silva MIPG, Vellosa SAG, Garcia ET 1997. Efficacy of an enzyme-linked immunosorbent assay in the diagnosis and serologic distinction between acute and chronic Schistosoma mansoni infection. Am J Trop Med Hyg 57: 358-362.

Van Helden HPT, Terpstra WJ, Okot-Kotber BM, Eyazuke VM 1975. Are there stage-characteristic immunofluorescence patterns in schistosomiasis? Trans $R$ Soc Trop Med Hyg 69: 309-311. 
